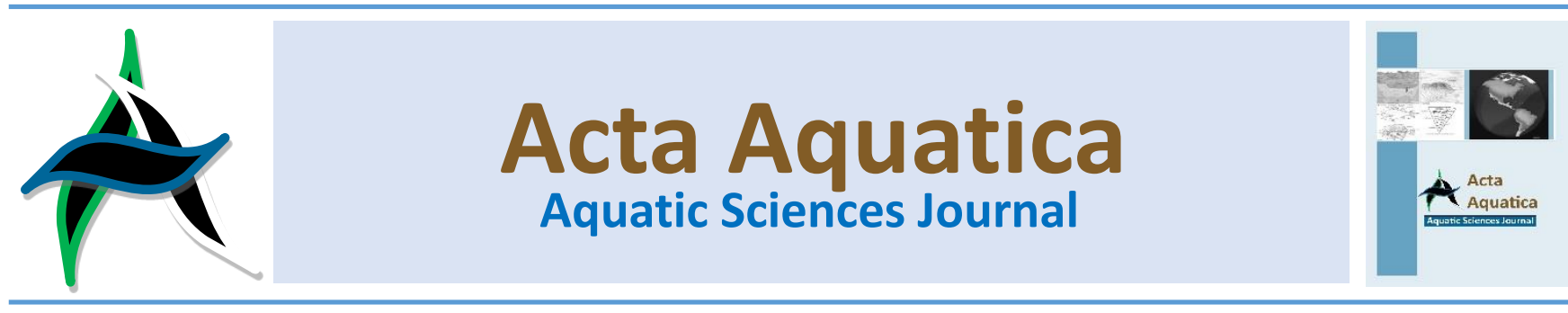

\title{
Biological properties of European bitterling Rhodeus amarus (Bloch, 1782) in Dinsiz Stream, Turkey
}

\author{
Semra Benzer ${ }^{a}{ }^{*}$, Ali Gül ${ }^{a}$ \\ ${ }^{a}$ Department of Science Education, Gazi University, Turkey
}

\begin{abstract}
The aim of this article was to some morphometric characteristics of Rhodeus amarus from Dinsiz Stream. A morphological analysis of 21 morphometric characters were done. These characteristics total length (TL); fork length (FL); standard length (SL); predorsal length; dorsal fin base length; dorsal fin length; head length; preorbital length; eye diameter; postorbital length; interorbital distance; body height; preanal distance; anal fin base length; anal fin length; pectoral fin base length; pectoral fin length; ventral fin base length; ventral fin length; caudal peduncle depth and weight (W). The samples were measured weight to the nearest $0.01 \mathrm{~g}$ and total, fork and standard length to the nearest $0.01 \mathrm{~mm}$. The total length $(\mathrm{TL})$ and weight $(\mathrm{W}$ min-max) of the fish were $4.2-7.1 \mathrm{~cm}$ and $1.699-7.444 \mathrm{~g}$, respectively.
\end{abstract}

Keywords: Rhodeus amarus; European bitterling; morphometric properties; Dinsiz Stream Turkey

\section{Introduction}

Rhoeus amarus (Bloch, 1972) has a wide distribution throughout Europe, where it inhabits a range of standing and slow-flowing habitats (Przybylski \& Zieba, 2000; Kottelat \& Freyhof, 2007). European bitter Rhodeus amarus, a small Cyprinid with a unique reproductive pattern, puts its females in freshwater mussel gills, where embryos develop for several weeks (Smith et al., 2004). Males fertilize the eggs by releasing sperm into the inhalant siphon of the mussel (Smith et al., 2004). The habitat of bitterling is linked to the distribution of freshwater unionid mussels. Typical habitats are river backwaters, oxbows, lakes, ponds, and irrigation canals (Holcik, 1999).

Life expectancy is exceptionally up to five years, but most individuals do not survive in their first reproductive years and the population sizes change drastically over the years (Kottelat \& Freyhof, 2007). It is most abundant in wet vegetation and sand silt bottom, lowland ponds, canals, slow-flowing rivers, singles, and still or slow-flowing waters with oxbows and mussels (Kottelat \& Freyhof, 2007). It is found among plants in shallow waters, on the sand and muddy bottoms. It attracts attention with its habit of leaving its eggs in the bivalves cavity. It feeds mainly on plants and to a lesser extent with worms, crustaceans and insect larvae (Maitland \& Campbell, 1992).

\footnotetext{
* Corresponding author: Department of Science Education, Faculty of Education, Gazi University Teknikokullar, Y. Mahalle, Ankara, Turkey Tel: +90.312 .2021608$

e-mail: sbenzer@gazi.edu.tr; sbenzer@gmail.com

doi: https://doi.org/10.29103/aa.v7i2.2479

The bitterling oviposits its eggs inside the branchial cavity of the freshwater mussels of Unio and Anodonta species (Reynolds et al., 1997; Smith et al., 2000a, Smith et al., 2000b) To understand how life history features are shaped, the biological features of a fish species must be explored for each habitat, as several studies have revealed the evolution of lifehistory related to environmental conditions (Roff, 1992; Stearns, 1992).

Some properties of Rhodeus amarus was investigated by Przybylski and Garcia-Berthou (2004) in Wieprz-Krzna Canal, Poland (TL mean 37.1-64.4), age and growth of European bitterling; Zaki et al. (2008) in Europea, Transcaucasia, Asia Minor and Eastern Russia, morphological and genetic analysis; Patimar et al. (2010), in Siahroud River Iran, (TL 27-84 cm), life history pattern; Moreva et al. (2017) in Alatyr River, morphological characteristics, reproduction and food habits; Konecna and Reichard (2011), in small lowland river, seasonal dynamics in population characteristics; Bektaş et al. ( 2013) the phylogenetic position.

The field of fishery science has employed many tools such as genetics and morphometric to differentiate the fish population (Mirr et al., 2013). Morphometric measurements are widely used to identify differences between fish populations (Cheng et al., 2005; Bujl et al., 2008; Tores et al., 2010). Systematic and phylogeographic studies based on morphometry are built on a series of measurements that represent size and shape variation and are continuous data. Morphological characters are widely used in fisheries biology to measure discrepancy and relationships between various taxonomic categories (Turan, 1999). Fish classification systems can facilitate fish counting, stock evaluation of ecological effects, 
monitoring fish behavior (Benson et al., 2009). The present study examines biological properties of Rhodeus amarus from Dinsiz Stream.

\section{Materials and methods}

\subsection{Study area}

Dinsiz Stream flows from Karasu to the Black Sea by passing through Hendek, Akyazı and Adapazarı districts of Sakarya. Samples were taken from Dinsiz Creek (Fig. 1).

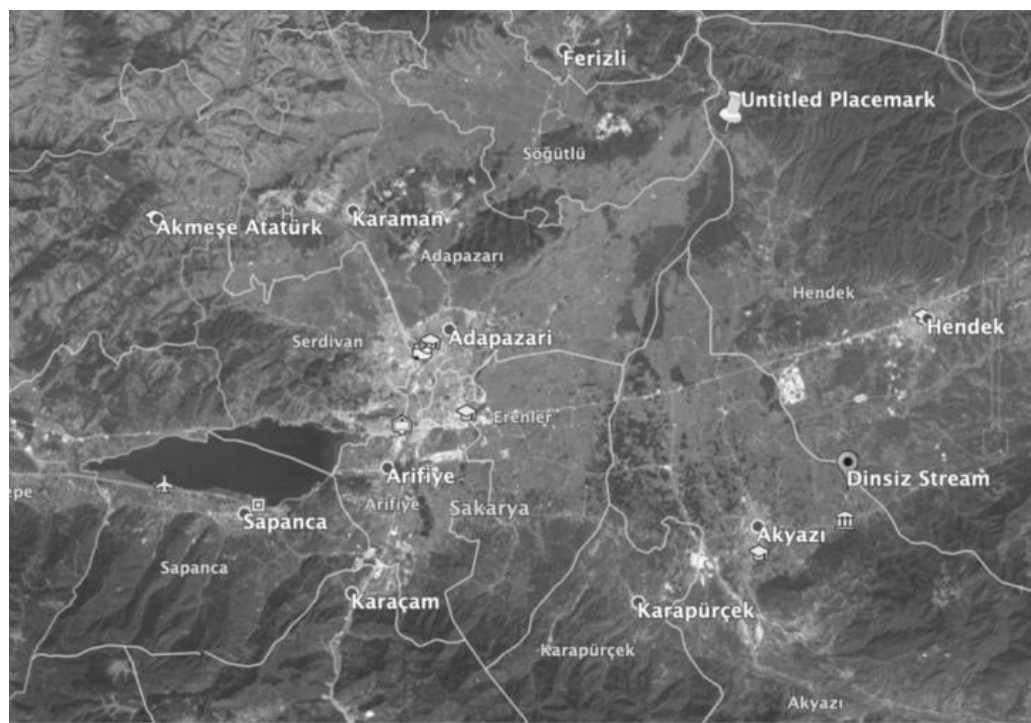

characteristics were measurements for morphometric characteristics (Fig. 2).

These characteristics were total length; fork length; standard length; predorsal length; dorsal fin base length; dorsal fin length; head length; preorbital length; eye diameter; postorbital length; interorbital distance; body height; preanal distance; anal fin base length; anal fin length; pectoral-fin base length; pectoral-fin length; ventral fin base length; ventral fin length; caudal peduncle depth and weight.

The length-weight relationship equation is the traditional calculation method used to determine the growth characteristics of fish populations. The length and weight values of the species were used for the relationship. The relations between total length (TL) and weight (W) for nearly all species of fishes can normally be represented by the "length-weight relationship" following equation:

$$
W=a T L^{b}
$$

$W(g)$ is the weight of fish, $L(\mathrm{~cm})$ is the length of fish, "a" and " $b$ " are constants. The parameter ' $b$ ' has an important biological meaning for fisheries, indicating the rate of weight gain relative to growth in length or the rate at which weight increases for a given increase in length. The growth is isometric if $b=3$ and the growth is allometric if $b \neq 3$ (negative allometric) (Rickter, 1973). The condition factor (CF) was calculated for all individual fish by using the conventional formula described by (Worthington \& Ricardo, 1936):

$$
C F=\mathrm{W} \frac{100}{L^{3}}
$$

Many streams such as Çark Stream, Dinsiz Stream, Mudurnu Stream, Darıçayır Stream, Karaçay Stream, Akçay Stream, Yırtmaç Stream, Sapanca Stream, Değirmendere are located on the Sakarya River.

\subsection{Methodology}

The samples, Rhodeus amarus were collected from Dinsiz Creek. During the study, 11 fish specimens were caught in 2016. The samples were preserved in \%4 formaldehyde solution and measured weight to the nearest $0.01 \mathrm{~g}$ and total, fork and standard length to the nearest $0.01 \mathrm{~mm}$. The

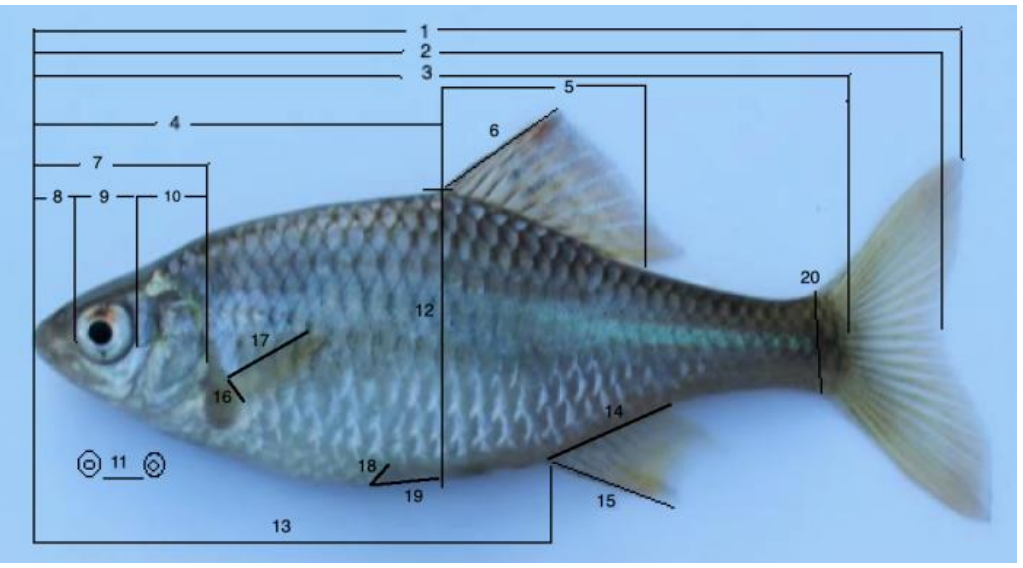

Figure 2. Morphometric characters for distance-based measurements. 1: total length; 2: fork length; 3 : standard length; 4: predorsal length; 5 : dorsal fin base length; 6: dorsal fin length; 7: head length; 8: pretorbital length; 9: eye diameter; 10: postorbital length; 11: interorbital distance; 12: body height; 13: preanal distance; 14: anal fin base length; 15: anal fin length; 16:pectoral fin base length; 17:pectoral fin length; 18:ventral fin base length; 19:ventral fin length; 20:caudal peduncle depth.
Where CF is condition factor, $\mathrm{W}(\mathrm{g})$ is the weight and $\mathrm{L}(\mathrm{cm})$ is the length.

\section{Result and discussion}

The standard length (SL) and weight (W min-max) of the fish were $4.20-7.10$ and $2.00-3.40 \mathrm{~g}$, respectively. A sample Rhodeus amarus was collected from Dinsiz Stream. 21 mensural characters, including SL, FL and TL and W were measured (Table 1). Length-weight relationships of Rhodeus amarus species in Dinsiz Stream were determined. The relationship was $\mathrm{W}=$ $0.01803262 \mathrm{SL}^{3.1538}\left(\mathrm{R}^{2}=0.942\right), W=0.16594513 \mathrm{TL}$ $2.0682\left(R^{2}=0.929\right)$ and $W=0.232557684 \mathrm{FL}{ }^{1.8502}\left(R^{2}=\right.$ 0.939 ) for all fish. Length-weight relationships equations for Rhodeus amarus are given in Fig. 3.

The condition factor (CF) of Rhodeus amarus was determined as 1.943-2.880 and 2.355 for min-max values and mean, respectively in Dinsiz Stream. Esmaeili et al. (2011) determined the average length values $\mathrm{TL}, \mathrm{FL}, \mathrm{SL}$, head length, head depth, head width, maximum body depth, minimum body dept and weight of Rhodeus amarus individuals in Zarrineh River as 43.25, 39.51, 35.3, $9.39,8.02,5.59,11.88,3.88$, and 1.11 , respectively. Li et al. (2020) determined the range length of male as 23.6-33.2 (SL). Besides, according to \% SL length value; head length, body depth, orbit diameter, predorsal length and caudal length has been determined as 22.9-25.6, 30.0-37.6, 7.6-9.5, 50.6 57.1 and $22.7-26.4$. 
Chan (2001) states that morphometric characters can change not only in populations but also in regions. It is stated that there are differences in morphological features and morphometric diversity of the population at the regional level (Francisco et al., 2006). Phylogenetically different freshwater fish have been shown to differ significantly between the ranges of their life stories (Mann et al., 1984; Lobon-Cervia et al., 1991 $\& 1996)$. Fish populations vary significantly in maximum size and age among habitats. This is about good habitat quality. Among other species of the Cyprinidae family, Rhodeus amarus has been found to have a reasonably short-lived fish and a life span not exceeding five years. The largest specimens of $84 \mathrm{~mm}$ $(11.14 \mathrm{~g})$ were in close agreements with $87 \mathrm{~mm}$ reported by Tarkan et al. (2005) for Ömerli Dam Lake's population of bitterling, another bitterling population in the southern limit of range distribution of this species. In the Elbe River systems, the females were larger than the males (Bauch, 1955), whereas Czech and Slovak's waters showed the opposite (Holcik, 1960).

Allometric growth was noted for several bitterling populations, and only the Severka River bitterling seemed to grow isometrically $(b=2.952)$ (Holcik,1999). The some properties of Rhodeus amarus was investigated by Koutrakis et al. (2003) in Rihios River, 1.2-8.3 (TL), b 3.035; Tarkan et al. (2006) in Marmara Lake, 5.7- 7.0 (TL), b=3.40; Patimar et al. (2010) in Siahroud River, 27-84 mm (TL) and 0.32-11.4 g for males and 30-64 mm (TL) and 0.52-4.06 g for females; Esmaeili et al. (2011) in Lake Orumiyeh, Mean 43.25 (TL), 39.51 (FL); illhan et al. (2014) in Sakarya 1.60-6.90 cm (TL), 0.06-5.03 g (W), b 2.948, in Yeşilırmak 5.50- $6.90 \mathrm{~cm}$ (TL), 2.52-4.83 g (W), b 2.884; in Gediz 2.20-8.30 cm (TL), 0.16-10.65 g (W), b 2.865, in Batı Karadeniz 5.40-7.10 cm (TL), 2.21- $6.22 \mathrm{~g}$ (W), b 3.374); Illhan and Sarı (2015) in Marmara Lake, $2.80-6.50 \mathrm{~cm}$ (TL), 0.26$4.49 \mathrm{~g}$ (W); Saç and Okgerman (2016) in Büyükçekmece Reservoir, 5.3- 8.2 (TL); 1.37-449 g (W) b 2.837; Gaygusuz et al. (2017) in Darlık Stream 1.5-8.6 (TL), 1.4- 7.9 (FL), 1.2- 6.9 (SL); Moreva et al. (2017) in Alatyr River 41-76 mm (FL).

Table 1

Morphometric characteristics of Rhoeus amarus specimens.

\begin{tabular}{|c|c|c|c|c|c|c|c|c|}
\hline Parameters & Min & Max & Average & SD & $\mathrm{Cl}$ & Margin of error & Upper bound & Lower bound \\
\hline Standard Length & 4.200 & 7.100 & 5.427 & 0.837 & 0.494 & 0.125 & 5.922 & 4.933 \\
\hline Fork Length & 3.100 & 6.500 & 4.500 & 0.962 & 0.569 & 0.165 & 5.069 & 3.931 \\
\hline Total Length & 3.200 & 5.900 & 4.509 & 0.823 & 0.486 & 0.121 & 4.995 & 4.023 \\
\hline Body Weight & 2.000 & 3.400 & 2.945 & 0.446 & 0.263 & 0.035 & 3.209 & 2.682 \\
\hline Head length & 0.800 & 1.500 & 1.027 & 0.205 & 0.121 & 0.008 & 1.149 & 0.906 \\
\hline Preorbital distance & 0.600 & 0.800 & 0.691 & 0.083 & 0.049 & 0.001 & 0.740 & 0.642 \\
\hline Eye diameter & 0.700 & 1.500 & 1.073 & 0.228 & 0.135 & 0.009 & 1.208 & 0.938 \\
\hline Postorbital distance & 0.200 & 0.400 & 0.300 & 0.063 & 0.037 & 0.001 & 0.337 & 0.263 \\
\hline Head depth & 0.200 & 0.400 & 0.300 & 0.063 & 0.037 & 0.001 & 0.337 & 0.263 \\
\hline Predorsal distance & 0.200 & 0.500 & 0.355 & 0.104 & 0.061 & 0.002 & 0.416 & 0.293 \\
\hline Prepelvic distance & 0.200 & 0.600 & 0.418 & 0.108 & 0.064 & 0.002 & 0.482 & 0.354 \\
\hline Preanal distance & 0.900 & 2.400 & 1.409 & 0.549 & 0.324 & 0.054 & 1.733 & 1.085 \\
\hline Pectoral fin - pelvic fin distance & 2.200 & 4.100 & 2.845 & 0.497 & 0.294 & 0.044 & 3.139 & 2.552 \\
\hline Pelvic fin - anal fin distance & 0.500 & 1.200 & 0.836 & 0.234 & 0.138 & 0.010 & 0.974 & 0.698 \\
\hline Body depth & 0.400 & 1.000 & 0.645 & 0.181 & 0.107 & 0.006 & 0.752 & 0.539 \\
\hline Dorsal fin (anterior end) - anal fin distance & 0.300 & 1.500 & 0.800 & 0.338 & 0.200 & 0.020 & 1.000 & 0.600 \\
\hline Dorsal fin (posterior end) - anal fin distance & 0.100 & 0.500 & 0.300 & 0.126 & 0.075 & 0.003 & 0.375 & 0.225 \\
\hline Postdorsal distance & 0.500 & 1.200 & 0.709 & 0.221 & 0.131 & 0.009 & 0.840 & 0.578 \\
\hline Postanal distance & 0.200 & 0.600 & 0.373 & 0.127 & 0.075 & 0.003 & 0.448 & 0.298 \\
\hline Caudal peduncle length (dorsal) & 0.400 & 1.000 & 0.636 & 0.169 & 0.100 & 0.005 & 0.736 & 0.537 \\
\hline Caudal peduncle length (ventral) & 0.400 & 0.800 & 0.545 & 0.144 & 0.085 & 0.004 & 0.631 & 0.460 \\
\hline Caudal peduncle depth & 1.699 & 8.444 & 4.043 & 2.031 & 1.200 & 0.735 & 5.243 & 2.843 \\
\hline
\end{tabular}

\section{Conclusion}

This article explains the area where Rhodeus amarus is located and records the morphometric data of the population. The findings obtained in this study are very important because previous studies on the morphometric properties of Rhodeus amarus have not been identified. It is considered that the data 
obtained in this article will contribute positively to future studies.

\section{Bibliography}

Bauch, G., 1955. Die einheimischen Süßwasserfische. Neumann: Radebeul u. Berlin. 3, 109-110.

Bektaş, Y., Beldüz, A. O., Turan, D., 2013. The phylogenetic position of Turkish populations within the European Bitterling, Rhodeus amarus (Osteichthyes: Cyprinidae). Zoology in the Middle East, 59(1): 39-50.

Chan, K. Y., 2001. An overview of some tillage impacts on earthworm population abundance and diversity implications for functioning in soils. Soil and tillage research, 57(4): 179-191.

Esmaeili, H. R., Nazari, N., Gholamifard, A., Gholamhosseini, G., Teimory, A., Coad, B. W., 2011. Range extension and translocation for Rhodeus amarus (Bloch, 1782) (Actinopterygii: Cyprinidae) in northwestern Iran. Turkish Journal of Zoology, 35(6): 882-885.

Francisco, S. M., Cabral, H., Vieira, M. N., Almada, V. C., 2006. Contrasts in genetic structure and historical demography of marine and riverine populations of Atherina at similar geographical scales. Estuarine, Coastal and Shelf Science 69: 655-661.

Gaygusuz Ö, Gaygusuz, ÇG, Dorak Z., 2017. Darlık deresi ve kollarının (Şile-ìstanbul) balık türü çeşitliliği. Turkish Journal of Bioscience and Collections. 1(1): 29-37. (Turkish).

Gülşah, S. A. Ç., Okgerman, H., 2016. Length-Weight Relationship, Length-Length Relationship and Condition Factor of Some Fish Populations in Büyükçekmece Reservoir (İstanbul, Turkey). Journal of Limnology and Freshwater Fisheries Research, 2(1): 43-48.

Holcik, J., 1999. Rhodeus sericeus (Pallas, 1776). Pages 1-32 in P.M. Banarescu, editor. The freshwater fishes of Europe Vol. 5/1, Cyprinidae 2/1. Aula-Verlag GmbH.

Holcık, J., 1960. Age and growth of the European bitterling (Rhodeus sericeus amarus) and notes on different methods of determination of age and growth of fishes. Rozpr. `Cesk. Akad. Ved Rada Mat. Prír. Ved, 70: 3-112.

Illhan, A., Sarı, H. M., 2015. Length-weight relationships of fish species in Marmara Lake, West Anatolia, Turkey. Croatian Journal of Fisheries: Ribarstvo, 73(1): 30-32.

IIlhan, A., Sarı, H. M., Ekmekçi, B., 2014. The Length-Weight Relationship of Bitterling, Rhodeus amarus (Bloch, 1782) in Freshwaters of Turkey. Journal of Fisheries Sciences.com, 8(3): 181-185.

Konečná, M., Reichard, M., 2011. Seasonal dynamics in population characteristics of European bitterling Rhodeus amarus in a small lowland river. Journal of Fish Biology, 78(1): 227-239.
Kottelat, M., Freyhof, J., 2007. Handbook of European Freshwater Fish. Kottelat, Cornol, Switzerland.

Koutrakis, E. T., Kokkinakis, A. K., Tsikliras, A. C., Eleftheriadis, E. A., 2003. Characteristics of the European bitterling Rhodeus amarus (Cyprinidae) in the Rihios river, Greece. Journal of Freshwater Ecology, 18(4): 615-624.

Li, F., Liao, T. Y., Arai, R., 2020. Two new species of Rhodeus (Teleostei: Cyprinidae: Acheilognathinae) from the River Yangtze, China. Journal of Vertebrate Biology, 69(1): 117.

Lobon-Cervia J., Montanes C., Sostoa A. de., 1991. Influence of environment upon life history of gudgeon, Gobio gobio (L.): a recent and successful colonizer of the iberian peninsula. J. Fish Biol. 39: 285-300.

Lobon-Cervia, J., Y. Dgebduadze, C. G. Utrilla, P. A. Rinco'n, C., Granado-Lorencio., 1996. The reproductive tactics of dace in central Siberia: evidence for temperature regulation of the spatio-temporal variability of its life history. Journal of Fish Biology 48: 1074-1087.

Maitland, P. S., Campbell, R.N., 1992. Freshwater fishes of the British Isles. Harper Collins Publishers, London.

Mann, R. H. K., Mills, C. A., Crisp, D. T.., 1984. Geographical variation in the life-history tactics of some species of freshwater fish. Pages 171-186 in G. W. Potts, and R. J. Wootton, editors. Fish reproduction: strategies and tactics. Academic Press, London.

Mir, F. A., Mir, J. I., Chandra, Suresh, 2013. Phenotypic variation in the Snowtrout Schizothorax richardsonii (Gray, 1832) (Actinopterygii: Cypriniformes: Cyprinidae) from the Indian Himalayas. Contributions to Zoology, 82(3) :115122.

Moreva, O. A., Predvighkin, M. A., Loginov, V. V., Vodeneeva, E. L., Postnov, D. I., Postnov, I. E. 2017. Morphological characteristics, reproduction, and food habits of European bitterling Rhodeus sericeus amarus (Cyprinidae) in the Alatyr River. Journal of Ichthyology, 57(5): 739-746.

Patimar, R., Seifi, T., Farahi, A., Ezzati, M., 2010. Life history pattern of the bitterling Rhodeus amarus (Bloch, 1782) in Siahroud River (southern Caspian SeaIran). Ecohydrology \& Hydrobiology, 10 (1), 87-95.

Przybylski, M., García-Berthou, E., 2004. Age and growth of European bitterling (Rhodeus sericeus) in the WieprzKrzna Canal, Poland. Ecohydrology and Hydrobiology, 4: 207-213.

Przybylski, M., Zieba, G., 2000. Microhabitat preference of European bitterling, Rhodeus sericeus in the Drzewiczka River [Pilica Basin]. Polskie Archiwum Hydrobiologii, 47(1).

Reynolds, J. D., Debuse, V. J. Aldridge, D. C., 1997. Host specialisation in an unusual symbiosis: European bitterlings spawning in freshwater mussels. Oikos 78: 539-545. 
Roff, D.A., 1992. The evolution of life histories. Chapman and Hall, New York.

Smith, C., Reichard, M., Jurajda, P., Przybylski, M., 2004. The reproductive ecology of the European bitterling (Rhodeus sericeus). Journal of Zoology, 262(2): 107-124.

Smith, C., Reynolds, J. D., Sutherland, W. J., 2000a. The population consequences of reproductive decisions. Proc. R. Soc. Lond. B Biol. Sci. 267: 1327-1334.

Smith, C., Reynolds, J. D., Sutherland, W. J., Jurajda, P., $2000 \mathrm{~b}$. Adaptive host choice and avoidance of superparasitism in the spawning decisions of bitterling (Rhodeus sericeus). Behav. Ecol. Sociobiol. 48: 29-35.

Stearns, S.C., 1992. The evolution of life histories. Oxford University Press, Oxford.

Tarkan, A. S., Gaygusuz, Ö., Acıpınar, H., Gürsoy, Ç., Özuluğ, M., 2006. Length-weight relationship of fishes from the Marmara region (NW-Turkey). Journal of Applied Ichthyology, 22(4), 271-273.

Tarkan, A.S., Gaygusuz, Ö., Gürsoy, Ç., Acı-pınar, H., 2005. Life history pattern of an Eurasian Cyprinid, Rhodeus amarus, in a large drinking-water system (Ömerli Dam Lake-Istanbul, Turkey). Journal Black Sea/Mediterranean Environment, 11: 205-224.

Zaki, S. A., Jordan, W. C., Reichard, M., Przybylski, M., Smith, C., 2008. A morphological and genetic analysis of the European bitterling species complex. Biological Journal of the Linnean Society, 95(2): 337-347. 